\title{
Penggunaan Model Contextual Teaching and Learning dalam Peningkatan Hasil Belajar Siswa SMP Kelas VIII Pada Mata Pelajaran Bahasa Indonesia
}

\author{
Ratih Marhaeni Juni Astuti \\ SMP Negeri 7 Muaro Jambi \\ Correspondence email: ratihmarhaeni88@gmail.com
}

\begin{abstract}
Abstrak. Model Pembelajaran merupakan suatu teknik pembelajaran yang digunakan guru dalam mengajarkan suatu pokok bahasan tertentu dan dalam pemilihan suatu model harus disesuaikan terlebih dahulu dengan materi pelajaran. Tingkat perkembangan kognitif siswa dan sarana atau fasilitas yang tersedia sesuai dengan tujuan pembelajaran sehingga model pembelajaran yang diharapkan dapat tercapai. Pelaksanaan pembelajaran tentang Penyampaian cerita dengan penerapan model Contextual Teaching And Learning (CTL). CTL merupakan konsep belajar yang membantu guru mengaitkan dengan situasi dunia nyata siswa dan mendorong siswa membuat hubungan antara pengetahuan yang dimilikinya dengan penerapan dalam kehidupan mereka sehari-hari. Model CTL berjalan sesuai dengan skenario yang ada pada Rencana Pelaksanaan Pembelajaran (RPP), dan telah berhasil menciptakan situasi belajar yang kondusif yakni siswa terlibat secara langsung pada proses pembelajaran, juga dapat meningkatkan hasil belajar siswa untuk belajar Bahasa Indonesia yang semula dianggap membosankan. Tingkat pemahaman siswa tentang penyampaian cerita setelah pembelajaran menggunakan model Pembelajaran CTL dapat meningkat dengan baik, ini dapat dilihat dari hasil evaluasi yaitu pada siklus 1 memperoleh nilai rata-rata 67 kategori cukup dan pada siklus ke 2 memperoleh nilai rata-rata 80 dengan kategori baik. Setelah diberikan tindakan dengan penggunaan penerapan Model Contextual Teaching and Learning (CTL) pada siklus 1 ketuntasan belajar siswa adalah 60\% atau 20 siswa. Sedangkan pada siklus II ketuntasan klasikal belajar siswa meningkat mencapai $94 \%$ atau 28 siswa
\end{abstract}

Kata Kunci: Hasil Belajar; Model Contextual Teaching And Learning

Abstract. Abstract Learning Model is a learning technique that is used by teachers in teaching a particular subject and in the selection of a model must be adjusted in advance with the subject matter. The level of cognitive development of students and the facilities or facilities available in accordance with the learning objectives so that the expected learning model can be achieved. Implementation of learning about the delivery of stories by applying the Contextual Teaching And Learning (CTL) model. CTL is a learning concept that helps teachers relate to students' real-world situations and encourages students to make connections between the knowledge they have and their application in their daily lives. The CTL model runs in accordance with the scenarios in the Learning Implementation Plan (RPP), and has succeeded in creating a conducive learning situation where students are directly involved in the learning process, can also improve student learning outcomes for learning Indonesian which was initially considered boring. The level of students' understanding of the delivery of stories after learning to use the CTL learning model can increase well, this can be seen from the results of the evaluation that in cycle 1, the average score of 67 categories was sufficient and in the second cycle it obtained an average score of 80 with a good category. After being given an action by using the application of the model of conventional teaching and learning (CTL) in cyle 1 students learning completeness is $74 \%$ or 20 Students. While in cycle 2 the classical learning achievement to $93 \%$ or 25 Students.

Keywords: Learning Outcomes; Contextual and Learning Model

\section{PENDAHULUAN}

Bahasa Indonesia merupakan mata pelajaran pokok dalam kurikulum pendidikan jenjang sekolah menengah pertama. Bahasa sangat berperan dalam mempengaruhi perkembangan intelektual, sosial, dan emosional siswa dan merupakan penunjang keberhasilan dalam mempelajari semua bidang studi. Pembelajaran bahasa ditujukan untuk membantu siswa mengenal dirinya, kebudayaan, mengemukakan gagasan dan perasaan, berinteraksi dalam masyarakat, dan menemukan serta menggunakan kemampuan analisa dan imaginasi yang ada dalam diri siswa itu sendiri. Pembelajaran bahasa Indonesia diarahkan untuk meningkatkan kemampuan siswa untuk berkomunikasi dalam bahasa Indonesia dengan baik dan benar, baik secara lisan maupun tulis, serta menumbuhkan apresiasi terhadap hasil karya kesastraan manusia Indonesia.(Maman Suryaman,2009).

Kurikulum Pendidikan di Indonesia mengalami perkembangan dan perubahan sesuai dengan kebutuhan dalam meningkatkan mutu pendidikan. Perubahan kurikulum tentunya akan berpengaruh kepada sistem pembelajaran. Di dalam konteks pembelajaran, kurikulum merupakan seperangkat rencana yang berisi tujuan, isi, dan bahan pelajaran serta cara yang digunakan sebagai pedoman penyelenggaraan kegiatan pembelajaran untuk mencapai tujuan pendidikan tertentu. Dengan demikian, kurikulum bukan hanya menjadi hiasan selama pertemuan di kelas antara guru dengan siswa, melainkan bagian terpenting di dalam 
mengubah karakteristik manusia Indonesia yang maju, modern, bermoral, berdisiplin, beretos kerja tinggi, menguasai kemampuan teknis dan profesional, memiliki sikap rasional dan kemampuan intelektual, demokratis, bertanggung jawab, serta makmur dan sejahtera.(Maman Suryaman, 2009).

Proses pembelajaran merupakan salah satu kegiatan yang sangat berperan dalam meningkatkan mutu hasil belajar. Guru sebagai pengelola pembelajaran di kelas bertanggung jawab atas keberhasilan pembelajaran yang pada akhirnya berpengaruh terhadap hasil belajar siswa. Terkait pencapaian hasil belajar tidak hanya dipengaruhi oleh peran guru dan siswa, tetapi juga dipengaruhi oleh metode atau strategi dalam melaksanakan proses pembelajaran. Untuk itu diperlukan memilih atau menggunakan metode yang efektif dan efisien dalam proses pembelajaran agar hasil belajar suatu mata pelajaran mendapatkan nilai yang maksimal.

Keberhasilan siswa dalam melaksanakan proses pembelajaran dapat diukur dari pencapaian hasil belajar yang mereka peroleh. Untuk meningkatkan hasil belajar siswa pada mata pelajaran Bahasa Indonesia diperlukan kreativitas guru dalam mengembangkan proses pembelajaran salah satunya melalui model Contextual Teaching and Learning (CTL). Model Pembelajaran CTL menurut Sanjaya (2006) menyatakan bahwa belajar dalam CTL bukan hanya sekadar duduk, mendengarkan dan mencatat, tetapi belajar adalah proses berpengalaman secara langsung. Lebih jauh ia mengupas bahwa Contextual Teaching and Learning (CTL) adalah suatu strategi pembelajaran yang menekankan kepada proses keterlibatan siswa secara penuh untuk menemukan materi yang dipelajarinya dan menghubungkannya dengan situasi kehidupan nyata, sehingga siswa didorong untuk dapat menerapkannya dalam kehidupan mereka. Sedangkan Blanchard dalam (Trianto, 2007) mengemukakan bahwa pembelajaran kontekstual adalah pembelajaran yang terjadi dalam hubungan yang erat dengan pengalaman sesungguhnya.

Selanjutnya Trianto (2007) mengemukakan bahwa CTL adalah pembelajaran yang terjadi apabila siswa menerapkan dan mengalami apa yang sedang diajarkan dengan mengacu pada masalah-masalah dunia nyata yang berhubungan dengan peran dan tanggung jawab mereka sebagai anggota keluarga dan warga masyarakat. Sejalan dengan hal di atas, Muslich (2007) menjelaskan bahwa landasan filosofi CTL adalah konstruktivisme, yaitu filosofi belajar yang menekankan bahwa belajar tidak hanya sekadar menghafal tetapi mengkonstruksi atau membangun pengetahuan dan keterampilan baru lewat fakta-fakta yang mereka alami dalam kehidupannya. Dengan mengacu pada beberapa pendapat di atas, pembelajaran CTL merupakan suatu konsep pembelajaran yang mengaitkan antara materi pelajaran yang dipelajari siswa dengan konteks di mana materi tersebut digunakan dengan menggunakan pengalaman dan pengetahuan sebelumnya untuk menemukan dan membangun pengetahuannya sendiri. Materi pelajaran akan bermakna bagi siswa jika mereka mempelajari materi tersebut melalui konteks kehidupan mereka.

Pembelajaran kontekstual (Contextual Teaching andLearning) adalah "konsep belajar yang membantu guru mengaitkan antara materi yang diajarkannya dengan situasi dunia nyata siswa dan mendorong siswa membuat hubungan antara pengetahuan yang dimilikinya dengan penerapannya dalam kehidupan mereka sehari-hari, dengan melibatkan tujuh komponen utama pembelaaran efektif, yakni: konstruktivisme (constructivism), bertanya (questioning), menemukan (inquiri), masyarakat belajar (learning community), pemodelan (modeling), dan penilaian sebenarnya (authentic assessment)". Secara teori ada beberapa model CTL yang terdiri dari langkah atau sintaks yang dapat diterapkan dalam proses pembelajaran didalam kelas. Langkah atau sintaks tersebut antara lain sebagai berikut : (1) Mengembangkan pemikiran bahwa anak akan belajar lebih bermakna dengan cara bekerja sendiri, menemukan sendiri dan mengkontruksi sendiri pengetahuan dan keterampilan barunya.(2) Melaksanakan sejauh mungkin kegiatan inquiri untuk semua topik. (3) Mengembangkan sifat ingin tahu siswa dengan bertanya. (4) Menciptakan masyarakat belajar (belajar dalam kelompok). (5) Menghadirkan model sebagai contoh pembelajaran. (6) Melakukan refleksi di akhir pertemuan dan (7) Melakukan penilaian yang sebenarnya dengan berbagai cara.

Model pembelajaran CTL memiliki kelebihan dalam penerapan, kelebihan dari model pembelajaran CTL adalah : (a) Memberikan kesempatan pada sisiwa untuk dapat maju terus sesuai dengan potensi yang dimiliki sisiwa sehingga sisiwa terlibat aktif dalam PBM.(b) Siswa dapat berfikir kritis dan kreatif dalam mengumpulkan data, memahami suatu isu dan memecahkan masalah dan guru dapat lebih kreatif. (c). Menyadarkan siswa tentang apa yang mereka pelajari. (d). Pemilihan informasi berdasarkan kebutuhan siswa tidak ditentukan oleh guru. (e). Pembelajaran lebih menyenangkan dan tidak membosankan.(f). Membantu siwa bekerja dengan efektif dalam kelompok. (g). Terbentuk sikap kerja sama yang baik antar individu maupun kelompok.

Beberapa komponen utama dalam pembelajaran Kontekstual menurut Johnson (2010), yang dapat di uraikan sebagai berikut: (1). Melakukan hubungan yang bermakna (Making Meaningful Connections). Keterkaitan yang mengarah pada makna adalah jantung dari pembelajaran dan pengajaran kontekstual. Ketika siswa dapat mengkaitkan isi dari mata pelajaran akademik, ilmu pengetahuan alam. Atau sejarah dengan pengalamannya mereka sendiri, mereka menemukan 
makna, dan makna memberi mereka alasan untuk belajar. Mengkaitkan pembelajaran dengan kehidupan seseorang membuat proses belajar menjadi hidup dan keterkaitan inilah inti dari CTL. (2). Melakukan kegiatan-kegiatan yang berarti (Doing Significant Works). Model pembelajaran ini menekankan bahwa semua proses pembelajaran yang dilakukan di dalam kelas harus punya arti bagi siswa sehingga mereka dapat mengkaitkan materi pelajaran dengan kehidupan siswa. (3). Belajar yang diatur sendiri (Self-Regulated Learning). Pembelajaran yang diatur sendiri, merupakan pembelajaran yang aktif, mandiri, melibatkan kegiatan menghubungkan masalah ilmu dengan kehidupan seharihari dengan cara-cara yang berarti bagi siswa. Pembelajaran yang diatur siswa sendiri, memberi kebebasan kepada siswa menggunakan gaya belajarnya sendiri. (4). Bekerjasama (collaborating) Siswa dapat bekerja sama. Guru membantu siswa bekerja secara efektif dalam kelompok, membantu siswa bekerja secara efektif dalam kelompok, membantu mereka memahami bagaimana mereka saling mempengaruhi dan saling berkomunikasi. (5). Berpikir kritis dan kreatif (Critical dan Creative Thinking). Pembelajaran kontekstual membantu siswa mengembangkan kemampuan berpikir tahap tinggi, nerpikir kritis dan berpikir kreatif. Berpikir kritis adalah suatu kecakapan nalar secara teratur, kecakapan sistematis dalam menilai, memecahkan masalah menarik keputusan, memberi keyakinan, menganalisis asumsi dan pencarian ilmiah. Berpikir kreatif adalah suatu kegiatan mental untuk meningkatkan kemurnian, ketajaman pemahaman dalam mengembangkan sesuatu. (6). Mengasuh atau memelihara pribadi siswa (Nuturing The Individual)

Dalam pembelajaran kontekstual siswa bukan hanya mengembangkan kemampuan-kemampuan intelektual dan keterampilan, tetapi juga aspek-aspek kepribadian: integritas pribadi, sikap, minat, tanggung jawab, disiplin, motif berprestasi, dsb. Guru dalam pembelajaran kontekstual juga berperan sebagai konselor, dan mentor. Tugas dan kegiatan yang akan dilakukan siswa harus sesuai dengan minat, kebutuhan dan kemampuannya. (7). Mencapai standar yang tinggi (Reaching High Standards). Pembelajaran kontekstual diarahkan agar siswa berkembang secara optimal, mencapai keunggulan (excellent). Tiap siswa bisa mencapai keunggulan, asalkan sia dibantu oleh gurunya dalam menemukan potensi dan kekuatannya. (8). Menggunakan Penilaian yang otentik (Using Authentic Assessment).Penilaian autentik menantang para siswa untuk menerapkan informasi dan keterampilan akademik baru dalam situasi nyata untuk tujuan tertentu. Penilaian autentik merupakan antitesis dari ujian stanar, penilaian autentik memberi kesempatan kepada siswa untuk menunjukkan kemampuan terbaik mereka sambil mempertunjukkan apa yang sudah mereka pelajari.
Proses pembelajaran mata pelajaran Bahasa Indonesia pada Kelas VIII di SMPN 7 Muaro Jambi berdasarkan hasil pengamatan dan evaluasi awal terhadap nilai ujian siswa pada semester ganjil tahun pelajaran 2018/2019 diperoleh data rata-rata nilai ujian siswa belum mencapai nilai KKM yang telah ditetapkan. Berdasarkan data awal ini peneliti melakuakan penelitian tindakan kelas sebagai upaya untuk meningkatkan hasil belajar siswa pada mata pelajaran Bahasa Indonesia. Selanjutnya peneliti melakukan telaah pustaka terkait teori model pembelajaran yang dapat meningkatkan hasil belajar, hasil telaah pustaka tersebut peneliti memutuskan untuk menggunakan model Contextual Teaching and Learning (CTL) sebagai model yang akan diterapkan dalam proses pembelajaran mata pelajaran Bahasa Indonesia.

Pemilihan model CTL untuk diterapkan dalam proses pembelajaran Bahasa Indonesia pada kelas VIII SMPN 7 Muaro Jambi, berdasarkan hasil kajian referensi yang penulis lakukan pada hasil penelitian yang telah dilakukan sebelumnya. Beberapa penelitian tindakan kelas terkait penerpan model CTL telah dilaksanakan oleh Ernayeti (2018) dalam penelitiannya yang berjudul Penerapan Model Pembelajaran Contextual Teaching And Learning Untuk Meningkatkan Hasil Belajar Ips Terpadu Siswa Kelas Viii Smp Negeri 2 Inuman. Tujuan dalam penelitian ini adalah untuk meningkatkan hasil belajar IPS terpadu siswa melalui penerapan model pembelajaran contextual teaching and learning. Hasil penelitian ini dapat disimpulkan bahwa penerapan model pembelajaran contextual teaching and learning dapat meningkatkan hasil belajar IPS terpadu siswa kelas VIII SMP Negeri 2 Inuman. Pada pertemuan II siklus II aktivitas siswa meningkat dengan skor 19 (67,86\%) dengan kategori cukup, pada pertemuan I siklus II aktivitas siswa mengalami peningkatan dengan perolehan skor 21 $(75,00 \%)$ dengan kategori baik. Dan pada pertemuan II siklus II aktivitas siswa kembali meningkat dengan perolehan skor $23(82,14 \%)$ dengan kategori sangar baik.

Penelitian metode CTL lainya dilakukan oleh Agus Darmawan (2017) dengan judul Penggunaan Model Pembelajaran Contextual Teaching And Learning (CTL) Untuk Meningkatkan Hasil Belajar Siswa Kelas Vii Mata Pelajaran Pendidikan Agama Islam Di Smp Negeri 1 Metro. Berdasarkan penelitian tindakan kelas dan pembahasan yang telah dilakukan, maka dapat disimpulkan bahwa pembelajaran dengan menggunakan model pembelajaran contectual teaching and learning (CTL) pada mata pelajaran Pendidikan Agama Islam mendapat kesimpulan sebagai berikut: Hasil belajar mata pelajaran Pendidikan Agama Islam pada awalnya sebelum menggunakan model pembelajaran CTL sebanyak $76 \%$ hasil belajar siswa yang belum mencapai target, namun setelah dilakukan penelitian dengan 
pembelajaran menggunakan model pembelajaran CTL dari siklus I ke siklus II, pencapaian hasil belajar siswa dapat meningkat sebesar $24 \%$, hal ini dapat dilihat dari hasil belajar yang dilakukan pada siklus I sebesar $60 \%$ dan pada siklus II sebesar $84 \%$ sehingga dapat dikatakan bahwa target dapat tercapai dibuktikan dari banyaknya siswa yang telah memperoleh nilai di atas KKM, dengan perhitungan siswa yang mencapai nilai $\geq 78$ di siklus II sebanyak 21 siswa, dan siswa yang mendapat nilai $<78$ hanya 4 siswa.

Berdasarkan penjelasan di atas, peneliti tertarik untuk melakukan sebuah penelitian dengan judul "Penggunaan Model Contextual Teaching And Learning Dalam Peningkatan Hasil Belajar Siswa SMP Kelas VIII Pada Mata Pelajaran Bahasa Indonesia”. Rumusan masalah dalam penelitian ini adalah apakah penerapan model pembelajaran contextual teaching and learning dapat meningkatkan hasil belajar Bahasa Indonesi siswa kelas VIII SMPN 7 Muaro Jambi, dan apakah dengan penerapan metode pembelajaran model CTL dapat meningkatkan partisipasi siswa dalam proses pembelajaran Bahasa Indonesia. Tujuan penelitian ini adalah untuk meningkatkan prestasi hasil belajar Bahasa Indonesia siswa kelas VIII dengan penggunaan model pembelajaran contextual teaching and learning dan meningkatkan partisipasi siswa dalam proses pembelajaran Bahasa Indonesia.

\section{METODE}

Penelitian ini dilaksanakan di SMP Negeri 7 Muaro Jambi, dengan subjek penelitian adalah siswa kelas VIII A SMPN 7 Muaro Jambi Kecamatan Jambi Luar Kota Desa Mendalo Darat tahun 2018/2019 dengan jumlah siswa 30 orang yang terdiri dari 16 orang perampuan dan 14 orang laki-laki. Penelitian ini merupakan penelitian tindakan (action research), karena penelitian dilakukan untuk memecahkan masalah pembelajaran di kelas.

Penelitian Tindakan Kelas ini dilakukan dalam dua siklus dengan menggunakan model yang dikembangkan oleh Suharsimi Arikunto. Tiap siklus terdiri dari empat tahap kegiatan yaitu menyusun rancangan tindakan atau tahap perencanaan, tahap pelaksanaan tindakan, tahap pengamatan dan tahap refleksi. Pelaksanaan penelitian tindakan kelas VIII ini mengikuti tahapan/siklus yang terdiri dari dua siklus yang meliputi: (1) perencanaan, (2) pelaksanaan tindakan, (3) observasi, dan (4) refleksi dalam setiap siklus (Arikunto, 2009). Kegiatan dibagi dalam dua siklus, yaitu siklus I dan II, dimana masing siklus dikenai perlakuan yang sama (alur kegiatan yang sama) dan membahas satu sub pokok bahasan yang diakhiri dengan tes formatif di akhir masing siklus (Arikunto, 2009). Teknik analisis yang digunakan dalam penelitian ini adalah teknik analisis deskriptif tentang hasil belajar Bahasa Indonesia yang diperoleh siswa.

\section{HASIL DAN PEMBAHASAN Pra Siklus}

Berdasarkan data awal hasil belajar Bahasa Indonesia Siswa kelas VIII A SMPN 7 Muaro Jambi sebelum diadakan tindakan kelas diperoleh data masih banyak siswa yang hasil belajarnya belum dapan mencapai tuntas sebagaimana indikator KKM yang ditetapkan. Persentase ketuntasan hasil belajar siswa kelas VIII A pada pelajaran Bahasa Indonesia hanya $34 \%$ siswa. Data tersebut disajikan pada tabel berikut.

Tabel 1. Data Awal Hasil Belajar Bahasa Indonesia Siswa

\begin{tabular}{cccc}
\hline No & Ketuntasan & Frekuensi & Persentase \\
\hline 1 & Tuntas & 10 & $34 \%$ \\
2 & Belum Tuntas & 20 & $66 \%$ \\
\hline
\end{tabular}

Sumber: Data Hasil Olahan

\section{Siklus I}

Penelitian tindakan kelas Siklus I dilaksanakan dengan menggunakan metode pembelajaran CTL, dengan menerapkan langkah/sintaks yang haruskan berdasarkan metode tersebut. Setelah semua tahapan siklus dilakukan mulai dari tahap perencanaan, pelaksanaan tindakan, observasi dan tahap refleksi. Maka dilakukan evaluasi dengan mengadakan tes ujian terhadap materi yang telah diberikan kepada siswa. Tes ini bertujuan untuk memperoleh indikasi seberapa besar tingkat penerimaan mahasiswa terhadap materi belajar dan efektifitas model pembelajaran.

Hasil belajar mata pelajaran Bahasa Indonesia Siswa kelas VIII A SMPN 7 Muaro Jambi setelah dilaksanakan tindakan kelas pada tahap siklus I, diperoleh hasil masih ada siswa yang hasil belajarnya belum tuntas. Persentase ketuntasan hasil belajar siswa kelas VIII A pada pelajaran Bahasa Indonesia sebesar $60 \%$ siswa. Hasil beljar siswa Siklus 1 disajikan pada tabel dan grafik berikut ini.

Tabel 2. Hasil Belajar Bahasa Indonesia Siklus 1 Siswa Kelas

\begin{tabular}{cccc}
\multicolumn{4}{c}{ VIII } \\
\hline No & Ketuntasan & Frekuensi & Persentasi \\
\hline 1 & Tuntas & 18 & $60 \%$ \\
2 & Tidak Tuntas & 12 & $40 \%$ \\
\hline
\end{tabular}

Sumber: Data Hasil Olahan

Pencapaian hasil belajar Bahasa Indonesia Siswa kelas VIII A SMPN 7 Muaro Jambi sebagaimana yang disasjikan pada tabel diatas menunjukkan masih terdapat siswa yang belum dapat menuntaskan pembelajaran Bahasa Indonesia, data menunjukkan masih ada sebanyak 12 siswa. Untuk siswa yang sudah dapat menuntaskan pembelajaran sebanyak 18 siswa memperoleh nilai rata-rata hasil belajar sebesar 67 , nilai ini berada pada kategori cukup. 


\section{Siklus II}

Penelitian tindakan dilanjutkan pada tahapan Siklus II. Tahapan penelitian tindakan kelas menerapkan prosedur yang sama dengan tahapan Siklus 1, yang terdiri dari tahap perencanaan, tahap tindakan kelas, tahap observasi dan tahap refleksi. Pada Siklus II, telah diadakan perbaikan dalam proses penerapan langkahlangkah model CTL. Hasil belajar Bahasa Indonesia Siswa kelas VIII A SMPN 7 Muaro Jambi setelah diadakan tindakan siklus II diperoleh hasil pembelajaran sebagaimana disajikan pada tabel berikut ini.

Tabel 3. Hasil Belajar Bahasa Indonesia Siklus II Siswa Kelas VIII

\begin{tabular}{cccc}
\hline No & Ketuntasan & Frekuensi & Persentasi \\
\hline 1 & Tuntas & 28 & $94 \%$ \\
2 & Tidak Tuntas & 2 & $6 \%$ \\
\hline
\end{tabular}

Sumber: Data Hasil Olahan

Hasil belajar Bahasa Indonesia Siswa kelas VIII A SMPN 7 Muaro Jambi setelah diadakan tindakan siklus II, menunjukkan jumlah siswa yang belum dapat menuntaskan hasil pembelajarannya sudah semakin menurun. Berdasarkan data yang disajikan pada tabel di atas siswa yang hasil belajarnya belum tuntas hanya terdapat 2 siswa atau sebesar 6\%. Untuk ketuntasan belajar siswa kelas VIII A SMPN 7 Muaro Jambi pada Siklus II mata pelajaran Bahasa Indonesia nilai tuntas adalah $93 \%$ dengan rata-rata nilai adalah 80 berada pada kategori baik.

Penelitian tindakan ini selain melihat peningkatan hasil belajar siswa dalam pembelajaran Bahasa Indonesia, juga ditujukan untuk mengamati keaktifan siswa dalam berpartisipasi pada proses pembelajaran Bahasa Indonesia. Berdasarkan data hasil tahapan observasi terhadap proses pembelajaran maka diperoleh hasil observasi aktivitas selama berlangsungnya proses pembelajaran sebagaimana disajikan pada tabel berikut ini.

Tabel 4. Hasil Observasi Aktivitas Siswa pada Siklus1

\begin{tabular}{|c|c|c|}
\hline No & Aspek Pengamatan & Siklus 1 \\
\hline 1 & Mendengarkan penjelasan guru & 5 \\
\hline 2 & $\begin{array}{l}\text { Mencatat hal-hal yang berhubungan dengan } \\
\text { materi }\end{array}$ & 10 \\
\hline 3 & $\begin{array}{l}\text { Bertanya kepada guru tentang hal-hal dalam } \\
\text { pembelajaran yang tidak dimengerti }\end{array}$ & 4 \\
\hline 4 & Mengemukakan pendapat dalam diskusi & 2 \\
\hline 5 & Mengerjakan Tugas tepat waktu & 7 \\
\hline \multirow[t]{4}{*}{6} & Mengumpulkan pada jam pelajaran berikutnya & 2 \\
\hline & Jumlah Skor & 30 \\
\hline & Total Skor & 36 \\
\hline & Persentase & $83 \%$ \\
\hline
\end{tabular}

Sumber: Data Hasil Olahan

Keterangan: Kreteria Penskoran

Skor $9-16=$ tidak aktif

Skor $17-23=$ kurang aktif
Skor $24-30=$ aktif

Skor $31-36=$ Sangat aktif

Kegiatan tahap observasi, ditujukan kepada 6 (enam) aspek pengamatan sebagaimana yang disajikan pada tabel diatas. Hasil observasi setiap aspek dilakukan penilaian atau pemberian skor sebagaimana kriteria penskoran yang telah ditetapkan. Aspek pengamatan tersebut berlangsung selama proses pembelajaran berlangsung. Hasil pengamatan terhadap aspek proses belajar pada Siklus 1 menghasilkan jumlah skor sebesar 30 dengan persentase $83 \%$ dari total skor. Nilai skor ini berada pada kategori sangat aktif.

Pada saat pembelajaran siklus I berlangsung, guru dan peneliti telah melakukan observasi terhadap jalannya proses pembelajaran. Setiap siswa menggunakan call card yang sesuai dengan nomor absen, sehingga memudahkan peneliti dalam mengobservasi siswa. Peneliti mengamati minat siswa di dalam kelas pada saat pembelajaran Bahasa Indonesia berlangsung. Selain itu peneliti juga mengamati proses jalannya diskusi dan presentasi kelompok. Hal itu dilakukan untuk menilai aspek afektif dan psikomotorik guna menilai prestasi belajar siswa. Dari hasil observasi yang dilakukan pada proses pembelajaran siklus I, siswa masih tegang dan kaku dalam mengikuti pembelajaran Bahasa Indonesia. Selain itu, masih banyak siswa yang bingung untuk mengerjakan soal evaluasi. Masih terlihat beberapa anak yang pintar saja, yang langsung bisa mengerjakannya.

Dari hasil observasi pada proses pembelajaran siklus I, kegiatan pembelajaran berjalan lebih baik. Siswa terlihat lebih antusias dalam mengikuti pembelajaran Bahasa Indonesia dengan pendekatan kontekstual. Kelompok siswa saling berebut untuk mempresentasikan hasil diskusi. Seluruh kelompok siswa selesai mengerjakan dan diperoleh jawaban yang benar.

Penelitian tindakan tahap observasi kembali dilakukan pada Siklus II, dengan menerapkan prosedur yang sama seperti pada Siklus 1, maka diperoleh hasil observasi pada Siklus II sebagaimana disajikan pada tabel berikut ini.

Tabel 5. Hasil Observasi Aktivitas Siswa pada Siklus II

\begin{tabular}{clc}
\hline No & \multicolumn{1}{c}{ Aspek Pengamatan } & Siklus II \\
\hline 1 & Mendengarkan penjelasan guru & 5 \\
2 & $\begin{array}{l}\text { Mencatat hal-hal yang berhubungan dengan } \\
\text { materi }\end{array}$ & 11 \\
3 & $\begin{array}{l}\text { Bertanya kepada guru tentang hal-hal dalam } \\
\text { pembelajaran yang tidak dimengerti }\end{array}$ \\
4 & Mengemukakan pendapat dalam diskusi & 4 \\
5 & Mengerjakan Tugas tepat waktu & 8 \\
6 & Mengumpulkan pada jam pelajaran berikutnya & 5 \\
& \multicolumn{2}{c}{ Jumlah Skor } \\
& Total Skor & 35 \\
& Persentase & $97 \%$ \\
\hline
\end{tabular}

Sumber: Data Hasil Olahan 
Ratih Marhaeni Juni Astuti, Penggunaan Model Contextual Teaching and Learning dalam Peningkatan Hasil Belajar Siswa SMP Kelas VIII Pada Mata Pelajaran Bahasa Indonesia

Keterangan: Kreteria Penskoran

Skor $9-16=$ tidak aktif

Skor $17-23=$ kurang aktif

Skor $24-30=$ aktif

Skor $31-36=$ Sangat aktif

Berdasarkan data yang disajikan pada tabel di atas menunjukkan terjadinya peningkatan keaktifan siswa dalam proses pembelajaran Bahasa Indonesia. Beberapa aspek pengamatan terjadi peningkatan skoring seperti pada aspek kedua dan kelima. Jumlah skor meningkat dari siklus 1 sebesar 30 menjadi 35 atau sebesar 97\% pada siklus II. Nilai Skor ini berada kategori Sangat Aktif. Pada saat pembelajaran siklus II berlangsung peneliti kembali melakukan observasi terhadap jalannya proses pembelajaran. Peneliti mengamati mengenai minat siswa di dalam kelas pada saat pembelajaran Bahasa Indonesia berlangsung.

Selain itu, peneliti juga mengamati kegiatan siswa pada saat melakukan diskusi dan presentasi kelompok untuk menilai aspek afektif dan aspek psikomotorik prestasi belajar siswa. Dari hasil observasi yang peneliti lakukan pada proses pembelajaran siklus II, kondisi kelas lebih kondusif dan tenang dari pada siklus I. Meskipun ditemukan satu kelompok yang masih kebingungan namun mereka tidak berisik dan tetap memperhatikan aktifitas kelompok laiinnya. Siswa terlihat tenang dan antusias. Masing-masing kelompok juga berebutan untuk mempresentasikan hasil diskusi di sepan kelas. Dari hasil observasi yang dilakukan pada proses pembelajaran siklus II, kegiatan pembelajaran berlangsung dengan baik. Kondisi kelas lebih kondusif dan kegiatan diskusi berjalan dengan lancar. Ada siswa yang hanya diam dalam kelompok, namun saat dihampiri ia mulai aktif dalam kelompoknya. Seluruh kelompok mengerjakan soal dengan cepat dan tepat waktu. Peningkatan aktivitas siswa dalam kegiatan pembelajaran Bahasa Indonesia dapat disajikan pada tabel berikut ini.

Tabel 8. Hasil Peningkatan Skor Aktivitas Siswa Dalam Kegiatan Pembelajaran

\begin{tabular}{cc}
\hline Siklus 1 & Siklus II \\
\hline $83 \%$ & $97 \%$ \\
\hline
\end{tabular}

Berdasarkan hasil skor dalam tabel di atas, pembelajaran Bahasa Indonesia pada materi "Berbahasalah Secara Persuasif" pada kelas VIII A di SMPN 7 Muaro Jambi pada siklus II mengalami peningkatan dari pada siklus 1 yang sebelumnya $83 \%$ meningkat menjadi $97 \%$. Artinya siswa dapat dikategorikan dalam kategori sangat aktif.

\section{Pembahasan}

Hasil belajar siswa pada mata pelajaran Bahasa Indonesia mengalami peningkatan. Peningkatan hasil belajar ini diperoleh setelah dilakukan tindakan kelas berupa penggunaan metode pembelajaran model Contextual Teaching and Learning yang diterapkan melalui tahapan Siklus 1 dan Siklus II dalam penelitian ini. Penerapan model pembelajaran ini juga meningkatkan partisipasi siswa dalam proses pembelajaran Bahasa Indonesia. Hal ini terlihat pada aktivitas mendegarkan penjelasan mata pelajaran, aktif mencatat, aktif bertanya dan aktif dalam diskusi kelompok. Penerapan model pembelajaran ini terbukti sangat membantu guru dalam pencapaian tujuan belajar.

Hal ini sesuai dengan pendekatan yang digunakan dalam penerapan model CTL itu sendiri. Menurut Hamdayama (2014) Pendekatan Contextual Teaching Learning merupakan konsep belajar yang membantu guru mengkaitkan antara materi yang diajarkan dengan situasi dunia nyata siswa dan mendorong siswa membuat hubungan antara pengetahuan yang dimilikinya dengan penerapannya dalam kehidupan mereka sebagai anggota keluarga dan masyarakat. Lebih lanjut dikemukakan Hamdayama (2014) Contextual Teaching Learning adalah suatu konsep belajar dimana guru menghadirkan dunia nyata ke dalam kelas dan mendorong siswa membuat hubungan antara pengetahuan yang dimiliki dengan penerapan dalam kehidupan sehari-hari, siswa memperoleh pengetahuan dan keterampilan dalam konteks yang terbatas sedikit demi sedikit, dan dari proses merekontruksi sendiri, sebagai bekal dalam memecahkan masalah kehidupannya sebagai anggota masyarakat.

Pada Siklus 1 diperoleh hasil pembelajaran Bahasa Indonesia dengan persentase ketuntasan hasil belajar siswa kelas VIII A sebesar $60 \%$ siswa atau sebanyak 18 siswa. Nilai rata-rata tes formatif pada akhir siklus 1 adalah 67 dengan kategori cukup. Penerapan tindakan kelas dengan model pembelajaran CTL berhasil meningkatkan nilai tes siswa pada Siklus kedua dengan nilai rata-rata mencapai angka 80.

Hasil belajar siswa yang diperoleh seperti pada tabel diatas ditetapkan $94 \%$ dari siswa memperoleh nilai diatas 65. Berdasarkan data pada tabel diatas diketahui bahwa hasil belajar siswa pada mata pelajaran Bahasa Indonesia materi "Berbahasalah Secara Persuasif" sudah mengalami peningkatan meskipun masih ada dua siswa atau sebesar $6 \%$ yang belum mencapai ketuntasan individual. Hasil penelitian dapat disimpulkan bahwa dalam pembelajaran siswa jika dilatih aspek kognitif, afektif, dan psikomotornya maka berdampak pada proses pembelajaran yang semakin efektif dan efisien.

Hasil refleksi pada tahap akhir siklus II dapat diidentifikasi implikasi hasil penelitian ini yaitu penerapan model CTL untuk meningkatkan hasil belajar Bahasa Indonesia siswa kelas VIII A SMPN 7 Muaro Jambi Kabupaten Muaro Jambi terbukti dapat meningkatkan keterampilan guru, aktivitas siswa, dan hasil belajar siswa kelas VIII A. Melalui penerapan model CTL guru dapat memberi kesempatan kepada 
siswa untuk aktif dalam proses pembelajaran. Penelitian ini dapat menambah pemahaman guru terhadap pemilihan dan penetapan strategi pembelajaran.

Berdasarkan penjelasan di atas, menunjukkan bahwa penerapan model pembelajaran contextual teaching and learning dapat meningkatkan hasil belajar Bahasa Indonesia siswa kelas VIII SMP Negeri 7 Muaro Jambi.

\section{SIMPULAN}

Penerapan model Contextual Teaching and Learning (CTL) dapat meningkatkan hasil belajar Bahasa Indonesia pada konsep penyampaian cerita di kelas VIII A SMPN 7 Muaro Jambi. Hal ini dapat dilihat dari meningkatnya ketuntasan hasil belajar siswa. Sebelum diberikan tindakan ketuntasan belajar siswa dalam kelas yaitu $37 \% \%$ atau 10 siswa. Setelah diberikan tindakan dengan penggunaan penerapan Model Contextual Teaching and Learning (CTL) pada siklus 1 ketuntasan belajar siswa meningkat menjadi $60 \%$ atau 18 siswa. Sedangkan pada siklus II ketuntasan klasikal belajar siswa meningkat mencapai $94 \%$ atau 28 siswa.

Berdasarkan hasil penelitian, peneliti memberikan beberapa saran antara lain:

a. Sekolah dapat memberi masukan kepada guru tentang upaya peningkatan hasil belajar dalam pembelajaran Bahasa Indonesia melalui penerapan model Contextual Teaching and Learning (CTL).

b. Bagi Guru dengan dilaksanakannya penelitian tindakan kelas ini, guru dapat menggunakan penerapan model Contextual Teaching and Learning (CTL) untuk meningkatkan hasil pembelajaran siswa.

\section{DAFTAR PUSTAKA}

Arikunto, Suharsimi. (2009). Peneltian TIndakan Kelas. Jakarta. Bumi Aksara

Darmawan, Agus (2017). Penggunaan Model Pembelajaran Contextual Teaching And Learning (Ctl) Untuk Meningkatkan Hasil Belajar Siswa Kelas Vii Mata Pelajaran Pendidikan Agama Islam Di Smp Negeri 1 Metro. Skripsi. Fakultas : Tarbiyah Dan Ilmu Keguruan Institut Agama Islam Negeri (IAIN) Metro.

Ernayeti (2018). Penerapan Model Pembelajaran Contextual Teaching And Learning Untuk Meningkatkan Hasil Belajar Ips Terpadu Siswa Kelas Viii Smp Negeri 2 Inuman. Jurnal PAJAR (Pendidikan dan Pengajaran). Program Studi Pendidikan Guru Sekolah Dasar FKIP Universitas Riau Volume 1 Nomor 1 Januari 2018.

Hamdayama, Jumanta. 2014. Model dan Metode Pembelajaran Kreatif dan Berkarakter. Bogor: Penerbit Ghalia Indonesia.

Johnson, B,E. (2010). Contextual Teaching and Learning. Bandung: Kaifa Learning.

Muslich, Masnur. 2007. KTSP Pembelajaran Berbasis
Kompetensi dan Kontekstual. Jakarta : Bumi Aksara.

Sanjaya, Wina. (2006). Strategi Pembelajaran Berorientasi Standar Proses Pendidikan. Jakarta: Kencana Prenada Media Group.

Suryaman, Maman. (2009). Panduan Pendidik Dalam Pembelajaran Bahasa Indonesia Smp/Mts. Jakarta: Pusat Perbukuan Departemen Pendidikan Nasional Republik Indonesia.

Trianto. 2007. Mendesain Model Pembelajaran InovatifProgresif. Surabaya. Kencana Prenada Media Group 